\title{
Behavioral and Personality Predictors of Acceptance and Rejection in University ${ }^{1}$
}

\author{
Daniel Bartholomeu ${ }^{2}$ \\ Centro Universitário Salesiano de São Paulo, \\ Americana-SP, Brazil
}

\author{
José Maria Montiel \\ Centro Universitário FIEO, \\ Osasco-SP, Brazil
}

\begin{abstract}
Acceptance and rejection in the group are related to both personality characteristics and social skills and most studies focus on children instead of college students. The objective of this study was to investigate whether acceptance and rejection would be more associated with personality tendencies, specifically socialization or social skills. We collected data from 187 college students attending the Physical Education (67\%) and Psychology (32\%) courses. The instruments were the sociometric test, the Factorial Scale of Socialization and the Social Skills Inventory. A moderating effect of gender in the relationship between assertiveness and acceptance and rejection to go out on college was observed. Social skills were better predictors of acceptance and social rejection in the university group.
\end{abstract}

Keywords: sociability, social skills, sociometry, college students

\section{Preditores Comportamentais e Personalidade na Aceitação e Rejeição em Universitários}

\begin{abstract}
Resumo: A aceitação e a rejeição no grupo associam-se tanto a características de personalidade como às habilidades sociais e são mais estudadas em crianças que em estudantes universitários. O objetivo deste estudo foi investigar se a aceitação e rejeição estariam mais associadas a tendências de personalidade, mais especificamente à socialização ou às habilidades sociais. Participaram 187 estudantes universitários dos cursos de Educação Física (67\%) e Psicologia (32\%). Os instrumentos utilizados foram o Teste Sociométrico, a Escala Fatorial de Socialização e o Inventário de Habilidades Sociais. Observou-se efeito de moderação do sexo na relação entre assertividade e aceitação e rejeição para sair em universitários. As habilidades sociais foram melhores preditores da aceitação e rejeição social no grupo de universitários.
\end{abstract}

Palavras-chave: sociabilidade, habilidades sociais, sociometria, estudantes universitários

\section{Predictores de Conducta y Personalidad en la Aceptación y el Rechazo en la Universidad}

\begin{abstract}
Resumen: La aceptación y el rechazo en el grupo se relacionan a las características de la personalidad y a las habilidades sociales, pero sin tener en cuenta la relación entre las habilidades sociales y personalidad. Además, los estudios son más centrados en los niños y no en los estudiantes universitarios. El objetivo fue investigar si la aceptación y el rechazo se asocian más con las tendencias de personalidad, específicamente con la socialización o las habilidades sociales. Recolectamos datos de 187 estudiantes universitarios de los cursos de Educación Física (67\%) y Psicología (32\%). Los instrumentos utilizados fueron la prueba sociométrico, la Escala Factorial de Socialización y el Inventario de las Habilidades Sociales. Se observó un efecto de moderación de género en la relación entre la asertividad y la aceptación y el rechazo para salir en la universidad. Las habilidades sociales son mejores predictores de la aceptación y del rechazo social en el grupo de estudiantes universitarios.
\end{abstract}

Palabras clave: sociabilidad, habilidades sociales, sociometría, estudiantes universitarios

Overall, different people are chosen for different activities, such as studying, going out, having sexual relations, whom to have fun with and so forth. Studies that looked into the relations between social skills and acceptance and rejection indicate that loved children possess normative and

\footnotetext{
${ }^{1}$ Paper deriving from the doctoral dissertation by the first author, under the advice of the second author and co-advice of the third author, defended in the Graduate Program in Psychology at the Universidade de São Paulo.

Support: National Council of Scientific and Technological Development (CNPq, Grant \# 00000/2000-0).

${ }^{2}$ Correspondence address:

Daniel Bartholomeu. UNISAL, campus Maria Auxiliadora, Departamento de Psicologia, Av. de Cillo, 3500, Parque Novo Mundo - SP. CEP: 13467-600. Americana, SP, Brazil. E-mail: d_bartholomeu@yahoo.com.br
}

friendly strategies, while children of low status tend towards greater aggressiveness (Kraus et al., 2014; Montiel et al., 2014; Morais, Otta, \& Scala, 2001). Sisto (2003) describes a higher acceptance level among colleagues for girls to the detriment of boys, and older children were characterized as more aggressive.

Evidence exists in the literature that the quality of the peer relationships since early predicts the future adjustment (Z.A.P. Del Prette, A. Del Prette, De Oliveira, Gresham, \& Vance, 2012; Feitosa, Z.A.P. Del Prette, \& A. Del Prette, 2012). Authors like Montiel, Bartholomeu and Pessotto (2014) consider that a person's skill in the relationships with peers who determine his/her success would correspond to the capacity to interpret the interpersonal and situational 
clues to achieve objectives, translate cognitive strategies into interpersonal behavior and monitor the results of his/her actions.

These ideas to interpret interpersonal and situational clues are also addressed in facial emotional and behavioral perception studies in social interaction situations. In fact, the combination between the bodily perception and the facial perception has demonstrated greater power to product the judgment of emotions in social interaction situations and consequently affects decision making in these contexts (Aviezer, Trop, \& Todorov, 2012; Ferreira \& Z.A.P. Del Prette, 2013; Freitas \& Z.A.P. Del Prette, 2015). In addition, the identification of nonverbal behavioral signs and their adequacy in social interaction situations has also been associated with good conversation skills and success in the social interactions in groups of people (Garg, Favre, Salamin, Hakkani-Tür, \& Vinciarelli, 2008; Vinciarelli, Pantic, \& Bourlard, 2009).

Rejected children are frequently considered as aggressive, disruptive, irritable, dominant, dishonest and selfish by their friends (Gresham \& Stuart, 1992; Kraus et al., 2014; McKown, Gumbiner, \& Johnson, 2011; Montiel et al., 2014; Morais, Otta, \& Scala, 2001). Their teachers tend to characterize them as having academic problems, improper behaviors and little physical attractiveness. In a recent study, Bartholomeu, Carvalho, Silva, Miguel and Machado (2011) investigated associations between social skills and acceptance-rejection, the latter being a variable of group relationships. The authors appointed that some social conducts can be employed in social skills training to avoid rejection among peers or even to maximize acceptance.

In the study by Bartholomeu, Montiel and Pessotto (2011), it was also indicated that boys who presented skills to cope with demands for expression of positive affect and for assertion of self-esteem, despite a minimal risk for an unwanted reaction, were more accepted and less rejected in the study situation. It is also important to highlight in this relation that although social skill and personality are individually associated with acceptance and rejection among colleagues, other studies have found relations between personality and social skills, such as the study by Bueno, S.M.S.S. Oliveira and J.C.S. Oliveira (2001).

It is worth emphasizing that, in those studies, social skills were defined as behaviors issued in the social context which maximize the change of social interaction and minimize damage, while personality was defined as a set of characteristics that are stable across situations and time (Bueno et al., 2001). Bartholomeu, Nunes and Machado (2008) analyzed the relations between socialization and social skills in college studies. The associations found were between kindness, self-assertion of positive affect and total social skills. Prosociability was also correlated with selfassertion of positive affect and self-control of aggressiveness. In addition, trust in people presented significant correlations with assertiveness, self-assertion of positive affect and selfcontrol of aggressiveness. The authors suggest that different personality aspects, particularly of the socialization trait, can affect certain characteristics of socially skilled behavior.

These associations suggest that greater control is due over these relations when establishing the correlations between some variable (social skills or socialization) and acceptance and rejection in the group, as other variables may exert interaction effects and somehow affect these relations (to give an example, with personality transporting the effect of the relations between social skills and acceptance/rejection of one of them in these relations). Bartholomeu, Carvalho, et al. (2011) have suggested this supposition, highlighting the interaction between these variables in the explanation of acceptance and rejection in the group.

The literature review by Gifford-Smith and Brownell (2003) also indicated that most studies involving social skills and acceptance and rejection among colleagues are concentrated on children, with a stronger focus on rejection, while fewer studies exist about acceptance. The authors emphasize that most studies about sociometry are concentrated up to the 1990's, with a lesser focus on college students, as most studies are focused on children. In addition, the social skills have also associations with personality trends (Bartholomeu et al., 2008; Bueno et al., 2001). Hence, although these two variable are associated with the sociometric measure, it is important to analyze which of these variables better explains acceptance and rejection in the group of college students in the situations of going out with colleagues and studying, which corresponds to the objective of this study. In a way, this information tests Moreno's supposition (1972), who supposed that the screen (two-way affective bonds established in the relation) would determine the acceptance and rejection in the group, the latter being more linked to the individual's personality and power to be spontaneous in the relationships, which is one of the characteristics of the personality trait studied here, i.e. socialization. In that sense, personality is supposed to be a better predictor of the acceptance in the group, to the detriment of social skills, as personality tends to be structural and corresponds to the subject's typical reactions, while social skills can be trained. This evidence combines the observations by Moreno (1972) with the current conception of acceptance and rejection.

In addition, despite evidences of sex differences in social skills and socialization measures, in studies like Bartholomeu, Carvalho, et al. (2011), Bartholomeu, Montiel and Bernstein (2014), Montiel et al. (2014), it has not been investigated yet whether the sex would moderate the relations between social skills and acceptance, rejection, social preference and social impact. That is relevant to investigate the effect size of sex in the suggested relations among personality, social skills and sociometric measures, representing a secondary objective of this study. The objective in this research was to investigate whether acceptance and rejection are more associated with personality traits, more specifically with socialization, or with social skills.

\section{Participants}

\section{Method}

The research participants were 187 college students from two private teaching institutions in an interior city in the state of São Paulo, Brazil who were studying physical education (67\%) and psychology (32\%). A convenience 
sample was collected and no participant was excluded, as we were interested in punctually analyzing a sample of college students. The mean age in the sample was 22 years $(S D=5.88)$, ranging from 18 till 61 years, with $68.3 \%$ of the individuals being up to 21 years of age. What sex is concerned, a larger number of women (57.2\%) were observed, although the distribution was similar $(p=.062)$. About $28 \%$ of the individuals were single and $41.7 \%$ only studies. Data from students in three classes were analyzed. At one of the colleges (two classes), the students were taking the fifth semester of the physical education (67.4\%) program. At the other college, two other classes were studied, being one in the second semester $(17 \%)$ and another in the sixth semester $(15.5 \%)$. The differences in the course semester and course were not significant, suggesting that their distributions are similar ( $p$ $=.143 ; p=.082$, respectively).

Although the sample subjects in this study are not similar in terms of age to the subjects of the SSI standardization sample, we thought it was important to investigate all participants, as they represent an analysis of the reality at the university under analysis. In addition, studies involving older subjects can also expand the use and interpretation possibilities of these tools in terms of validity. At the same time, it is interesting and important to include most students from the classes in the research, as they also affect the group dynamics in terms of the sociometric choice. Therefore, we chose to maintain all people in the classes.

\section{Instruments}

The following instruments were used:

Social Skills Inventory - SSI-Del-Prette (Z.A.P. Del Prette \& A. Del Prette, 2001). This instrument consists of 38 items that describe situations of social interaction and people are instructed to assess how frequently they occur on a five-point scale (ranging from never to always). Factor one, coping with risk, consists of 11 items, which picture interpersonal relationship situations in which the defense of rights and self-esteem is affirmed. The second factor presents seven items and refers to self-assertion in the expression of positive affect. The third dimension is called conversation and social resourcefulness and contains seven items that involve neutral social situations that demand conversation practice. The fourth factor, self-exposure to unknown people or new situations, contains four items that inform about the approach of unknown people. Finally, in factor five, the dimension control of aggressiveness towards aversive situations. Its three items suppose a reaction to aversive stimuli that demand good control of aggressiveness. The psychometric properties of the SSI are available for review in Z.A.P. Del Prette, A. Del Prette and Barreto (1998). As regards its psychometric properties, it presents, among other studies, validity evidence based on its internal structure, calculated by factorial analysis using the alpha factor extraction and varimax rotation method. This provided for a five-factor solution that explained $92.75 \%$ of variance (Z.A.P. Del Prette et al., 1998). The internal consistency by Cronbach's alpha for these factors revealed coefficients between .74 and .97 . Other validity studies for this test are available in Bueno et al. (2001) and Z.A.P. Del Prette et al. (1998).

Factorial Scale of Socialization (Nunes \& Hutz, 2007b). The FSS is an objective scale that consists of 70 self-reported items, which assess Socialization in the model of the Big Five Personality Traits. The answers are given on a seven-point Likert scale, anchored at the ends, ranging from I Completely Disagree to I Completely Agree. The FSS consists of three facets, called Kindness (S1), Prosociability (S2) and Trust in People (S3), assessed by 33,23 and 14 items, respectively. Psychometric properties are available for review in Nunes and Hutz (2007a). To validate the FSS construct (Nunes \& Hutz, 2007b), a sample of people from five Brazilian states was used, with an average age of 21.4 years $(\mathrm{SD}=5.84)$. Factorial analyses were executed to verify the dimensions of the FSS. The internal consistency of the factors S1, S2 and $\mathrm{S} 3$, calculated by means of Cronbach's alpha, corresponded to $.91, .84$ and .80 , respectively. The internal consistency of the general scale was 0.92 .

Sociometric Measure. This measure is intended to capture a person's acceptance or rejection by his classmates for the activities of going out with colleagues and studying. Therefore, first, each student was asked to indicate three classmates with whom (s)he would like to study, as well as the reasons for choosing each of them. Thus, the first classmate indicated was considered the person with whom he most likes to study and so forth. We inquired about the reason for accepting the colleague. Next, the students was asked to indicate three classmates with whom (s)he would not like to study, the first chosen being the most rejected for this activity and so forth. In this case, again, the reasons were asked for rejecting each classmate indicated. The same questions were also asked for the activity of going out with friends. The positive indications for each of the situations received positive points, as follows: +3 for the first chosen; +2 for the second; and +1 for the third. Negative points, then, were attributed as follows: -3 for the least chosen; -2 for the second least chosen; and -1 for the third. Based on these scores, each student's sociometric position was found by the arithmetic sum of the acceptance and rejection scores in each situation. Thus, three measures were obtained. The first was related to the acceptance-rejection to study, another to going out with colleagues, and a general measure, which is the sum of the previous two situations. In addition, in line with Bartholomeu et al. (2014), the social preference was calculated, subtracting standardized values ( $Z$ scores based on the study sample) of the number of indications about who liked best and who liked least; and the social impact by the sum of the standardized scores about who liked best and who liked least. Although these two measures can be combined to derive the sociometric categories (popular, rejected, neglected, controversial and average), social preferences and impact were also used as dependent variables of the model as well.

\section{Procedure}

Data collection. The instruments were applied collectively in the classroom after the teachers and the 
institutional board's consent. The participation in the study was voluntary. The study participants were asked to sign the informed consent form, in compliance with the ethical standards for research involving human beings. The students were not selected in function of the semester they were taking. These scales were applied according to the instructions present in their technical manuals.

Data analysis. The FSS and SSI results were surveyed according to the procedures described in their technical manual. To compare the results of the present sample with the normative group of the FSS and SSI, the participants' Z-score was calculated, considering the means and standard deviations of the normative sample in function of the sex and compared between men and women using Student's t-test. These analyses were developed in SPSS 20. Next, the regression analysis was applied, using the FSS and SSI factors as independent variables and sex as the hypothetic moderating variable, in line with the secondary research objectives, and acceptance, rejection, social preference and social impact in the situations studied as dependent variables. In the linear regression analysis, the backward method was employed, as we chose to use the most important variables in this model, a method already adopted in other studies on the theme, such as Bartholomeu, Carvalho, et al. (2011), Bartholomeu et al. (2014), Montiel et al. (2014). To analyze the moderating effect, the software R was used. The package QuantPsyc and the function moderate.lm were used to estimate the moderating effect of the sex in the relations among social skills, socialization and social acceptance/rejection.

\section{Ethical Considerations}

The study received approval from the Research Ethics Committee at UNIFIEO, under protocol CAAE: 34710414.8.0000.5435.

\section{Results}

The mean gross scores, standard deviations and t-test results per sex are displayed in Table 1. Based on these data, the measures self-assertion in the expression of positive feelings, self-exposure to unknown individuals and new situations, selfcontrol of aggressiveness and prosociability distinguished the participants' sex. No significant differences per sex were found in the sociometric measures. The distribution of the measures was normal, and all factors did not evidence significance on the Kolmogorov-Smirnov test. What the sociometric test is concerned, the rejection scores were higher in comparison with the acceptance scores. About $28 \%$ of the people presented rejection scores for both situations, approximately $25 \%$ in the studying situation and $24 \%$ for going out. Concerning the descriptive statistics for this instrument, approximately 55\% of the people were chosen neither for studying nor for going out. With regard to the rejections, about $70 \%$ of the participants were not rejected by any fellow group member. In fact, only one person was highly accepted for studying, receiving 23 acceptances for this situation, and three participants received up to 15 acceptances. In the going out situation, only three people received between 13 and 15 acceptances.

Table 1

Mean and standard deviation of $z$ scores and t-test results for the $\operatorname{SSI}(N=187)$

\begin{tabular}{|c|c|c|}
\hline Dimension & $M$ & $S D$ \\
\hline \multicolumn{3}{|l|}{ Social Skills Inventory } \\
\hline Coping and self-assertion with risk & 0.20 & 1.03 \\
\hline $\begin{array}{l}\text { Self-assertion in the expression of positive } \\
\text { feelings* }\end{array}$ & 0.22 & 1.09 \\
\hline Conversation and social resourcefulness & 0.45 & 0.98 \\
\hline $\begin{array}{l}\text { Self-exposure to unknown people and new } \\
\text { situations* }\end{array}$ & 0.30 & 0.99 \\
\hline Self-control of aggressiveness* & 0.10 & 0.65 \\
\hline Scale & $M$ & $S D$ \\
\hline \multicolumn{3}{|c|}{ Factorial Scale of Socialization } \\
\hline Kindness & -0.44 & 0.98 \\
\hline Prosociability * & -0.40 & 0.99 \\
\hline Trust & -0.25 & 0.93 \\
\hline Total FSS & -0.42 & 0.90 \\
\hline
\end{tabular}

Note. * Differences significant at 0.05 per sex.

According to the analyses developed, first, we intended to analyze which of the socialization and social skills dimensions (dependent variables) better explained the acceptance and rejection in the groups for both activities (independent variables), in view of the supposition that the variables would be different; then, we intended to analyze which of the dependent variables would better explain the preference and social impact, as suggested by Bartholomeu et al. (2014), to respond to the main research objectives. Although sex differences were evidenced in four of the measures analyzed, the secondary objective in this study was to analyze the moderating effect of sex on the relations among social skills, socialization and the sociometric measure. Thus, sex was included as a moderating variable in the regression analysis model to analyze the interactions with the other independent variables in the model. Thus, we could analyze what beta coefficients the sex influences. The summary of the models with a significant ANOVA and explained variance percentage (Eta2) for each per sex is displayed in Table 2, together with the F scores, significance levels and total degrees of freedom. No multicollinearity was observed between the dependent variables superior to the tolerable levels, as the VIF and Tolerance factors indicate. The significant data in these regression analyses are displayed in Table 2 . It is interesting to observe that the sex variable only presented a moderating effect in the relations between the variables coping with risk (IV) and acceptance, rejection and social preference to go out (DV). Thus, one may say that a different effect per sex exists in these associations between these variables, but not in the other associations. 
Table 2

Summary of linear regression with backward method of SSI and FSS dimensions (independent variables) and acceptance and rejection to study and go out and of the moderation effect of the sex variable in these relations $(N=186)$

\begin{tabular}{lcccc}
\hline \multicolumn{1}{c}{ Model DV/IV } & $\mathrm{R}^{2}$ & $\mathrm{~F}$ & $p$ & Standardized Beta coefficient \\
\hline Acceptance studying / SSI 5 & 0.29 & 4.05 & .05 & 0.152 \\
Acceptance going out / SSI 1 & 0.46 & 7.89 & .01 & 0.321 \\
Rejection going out / SSI 1 & 0.25 & 6.98 & .02 & -0.38 \\
Social pref. studying / SSI 5 & 0.32 & 6.21 & .00 & -0.191 \\
Social pref. going out / SSI 1 & 0.54 & 10.31 & .00 & 0.323 \\
\hline & & Moderation effects of sex & -0.05 \\
Acceptance going out /SSI1*sex & 0.33 & 3.12 & .02 & 0.49 \\
Rejection going out /SSI1*sex & 0.24 & 2.90 & .05 & 0.62 \\
Social preference & 0.61 & 3.98 & .01 & 0.00 \\
Going out /SSI1*sex & & & \\
\hline
\end{tabular}

Note. DV = Dependent Variable; IV = Independent Variable; SSI1 = coping with risk; SSI 2 = expression of positive affect; SSI3 conversation and social resourcefulness; SSI4 = self-exposure to the unknown; SSI5 self-control of aggressiveness

*Interaction effect

\section{Discussion}

According to the results described, independently of the sex, which presented no significant effect in this case, it can be verified that only the self-control of aggressiveness in social interaction situations explained the acceptance to study. This trend can be interpreted as, for every point of acceptance to study, the self-control of aggressiveness increases by 0.152 . All other coefficients are interpreted similarly. In secondary education students, Bartholomeu, Montiel, et al. (2011) evidenced associations between skills to express positive affect and acceptance to study in men, but not in women. In this sense, the question can be asked how age affects the relations between social skills and sociometric measures as, for different phases of life and group configurations, distinct socially able conducts tend to explain the acceptance and rejection among colleagues.

A distinct situation is observed for the acceptance to go out, as the skills to cope with social situations in case of risk of rejection by the interlocutor (assertiveness) were good predictors of acceptance in this situation. These conducts to go out socially may be necessary and adaptive and, therefore, better accepted conducts, due to the context people tend to be submitted to, that is, to go out with friends to parties, perhaps facing the risk of social rejection and proposing what one finds good and relevant to do can be a necessary conduct. This fact demands further research. One question that can be raised is whether these people's conflict solution style does not tend to be more aggressive, which tends to be reproduced in the peer group and can be related with the parental educative styles, as Silva, Oliveira, Bandeira and Souza (2012) suggest.

Concerning the rejection to go out, assertiveness (coping with risk of rejection by the interlocutor) was negatively associated with the rejection in this situation. Hence, the higher the assertiveness, the less rejection to go out was experienced. In the research by Bartholomeu, Carvalho et al. (2011), the authors evidenced associations in men between self-control of aggressiveness and rejection to go out, as opposed to the result evidenced here. Nevertheless, in this research, not only Physical Education, but also Psychology students were analyzed in this study. Therefore, the question should be asked whether the profile in other personality variables, linked to the students in each course, would not affect the relations between social skills and rejection to go out for example.

None of the research variables explained the rejection to study, in turn. It should be taken into account that most research participants and study situations are linked to Physical Education, in which the practical part is frequently required in these assessments, characterizing a study activity that, besides intellectual work (reading, recalling information), demands physical performance, which can partially explain these results. Similar results had also been identified in the study by Bartholomeu, Carvalho et al. (2011) and Bartholomeu, Montiel et al. (2011), in college students as well as secondary education students, respectively.

It is important to highlight that, in these variables, the moderating effect of the sex variable on these relations between acceptance and rejection and social preference to go out and coping with risk was also observed. In fact, sex differences in the sociometric measures have not been evidenced either in the Brazilian and international literature and one of the possibilities to explain this fact is that the sociometric measure is a more global assessment of the outcomes the (verbal or non-verbal) social behavior provokes in the group. Hence, what commonly differs are the motives and justifications for choosing one or another subject in the group (Gresham \& Stuart, 1992; Hayden-Thomson, Rubin, \& Hymel, 1987; Kraus et al., 2014; McKown et al., 2011; Morais et al., 2001; Bernstein et al., 2010).

There is a lack of studies that analyze moderating variables of these relations between individual aspects and the sociometric measure, which calls for further research. The 
social skills differ per sex, with women being normally more skillful than men in these aspects (Bartholomeu, Carvalho, et al., 2011; Bartholomeu, Montiel, et al., 2011; Gifford-Smith \& Brownell, 2003; Ferreira \& Z.A.P. Del Prette, 2013). The literature also suggests differences in the associations between social skills and social acceptance and rejection per sex (Bartholomeu, Carvalho, et al., 2011; Bartholomeu, Montiel, et al., 2011). Nevertheless, it was unknown whether these effects actually differed, and the data indicate that the effects of these associations between social skills and acceptance and rejection to go out only differed for assertiveness. Hence, caution is due when interpreting the relations between social skills and acceptance/rejection in the group, as the existing sex differences in the social skills do not affect group cohesion similarly per sex. This information is relevant, as socially skillful behavior should be a way to improve the individual's social performance in the group, favoring his/her acceptance in the group to some extent. Hence, the sociometric measure would be a measure of the individual's social efficacy and knowing the impact the sex can exert in this relation implies the supposition of differential treatments for these skills during the training, which demands further research in other studies.

Some studies have focused on multilevel aspects involved in peer choice, considering the acceptance and rejection level of the classrooms at the second level and individual characteristic that influence this aspect. It is interesting to observe that some classes tend to produce more acceptances and others more rejections and the control of these group trends changes the focus of social behavior from the individual to the group. In fact, as emphasized, social acceptance and rejection are products of social interaction and not only individual skills, but also the group's characteristics directly affected these aspects. That seems to be a current trend in international research in this area and deserves further exploration (Bartholomeu et al., 2014; Selfhout, Branje, Delsing, ter Bogt, \& Meeus 2009).

The analysis of the findings thus far reveals that, overall, the social skills variables were more associated with the sociometric measures than the personality variables, emphasizing their greater power to predict attraction and rejection in the group and emphasizing that social behavior tends to be more learned and less related to more stable personal characteristics. It is interesting to note that the types of socially skillful behaviors or personality characteristics that explain acceptance and rejection varied due to the situation these variables were linked to. That originates the premise that different standards of conduct exist that explain the acceptance and rejection for each specific activity, evidencing the complexity of this model.

Other studies should focus on verifying common characteristics or a general factor for group acceptance or rejection, independently of the sex or activity. Using the variable social preference and social impact, it was observed that the social preference to study and to go out was explained by the self-control of aggressiveness in the relationship and by coping with risk (assertiveness), respectively. It should be highlighted that the effect of sex on social preference was even smaller than in the other conditions. That can be explained by the fact that this measure is more filtered for group acceptance, as the preferred persons are not only better accepted, but also less rejected in the group. Some people are highly accepted by one part of the group and highly rejected by another part (controversies in Moreno's theory (1972) and having great social impact) and are commonly more dominant in the group and similar to the centroid of a group (indication obtained by social network analysis measures), evidencing different characteristics of the individuals highly acceptance in the group (preferred). New studies can analyzed the effect of sex on these centroid subjects as well (Gifford-Smith \& Brownell, 2003; Serrat-Capdevila, Browning-Aiken, Lansey, Finan, \& Valdés, 2009).

Some studies have indicated that both facial expressions and body cues are useful to identify emotions and play an essential role in social acceptance and rejection, such as Aviezer et al. (2012), who tested whether, during the expression of intensive positive or negative emotions, people would be able to distinguish them. Three experiments were used in which images showing only faces expressing intense positive or negative emotions and whole bodies were shown to the participants. The authors manipulated positive faces on negative bodies and vice-versa. The results appointed that the effect of body cues is fundamental in the perception of intense positive and negative emotions, and not only the facial perception, revealing the importance of taking into account body cues in the emotional and social perception (Ferreira \& Z.A.P. Del Prette, 2013).

DeWall et al. (2011) also investigated the consequences of social exclusion in four experiments in which the threat of social exclusion increased the individuals' selective attention to smiling faces, reflecting a greater focus on signs of acceptance. People under threat of exclusion more rapidly identified smiling faces among other neutral ones. Hence, the authors conclude that the threat of exclusion motivates people to connect with sources of acceptance, such as the physical type. Again, in facial and physical expressions, first, the interaction situation itself was emphasized.

In fact, when interacting socially, we seek initial physical signs that make us perceive the right time to start a conversation or to ask something (Bartholomeu, Carvalho, et al., 2011; Currie \& Little, 2009; DeWall et al., 2011; Ferreira \& Z.A.P. Del Prette, 2013; Malinauskas \& Emeljanovas, 2013; Verosky \& Todorov, 2013). It is supposed that people with a sociable personality or who are highly able in social terms express more signs of opening to social contact, and are also more attentive to these signs in interactions. The studies by Aviezer et al. (2012) did not consider this control by the personality and social skills characteristics.

One interesting suggestion to articulate the studies that analyze emotional and social skills factors with the characteristic behaviors that are transmitted in the social interaction would be to consider the contributions of social intelligence to the analysis of the social signs, as suggested in studies like Garg et al. (2008), Vinciarelli et al. (2009) and Vinciarelli, Pantic, Bourlard and Pentland (2008), among others. It should be mentioned that none of these also used the sociometric technique or personality measures or emotions to 
control these aspects or even know if certain signs explain the acceptance in the group.

In that sense, this study contributes to what is described in the literature, expressing that, analyzed in combination with personality characteristics and sex, the social skills present a greater effect on the social preference and social acceptance and rejection. This fact tends to partially support the suppositions by Moreno (1972) in the creation of the sociometric test, in which the author postulates that personal, affective (tele) and personality characteristics would explain the acceptance in the group, as personality does not exert such a great effect as the learned social behavior. Hence, people can be equipped to obtain greater acceptance in the group based on their social behavior, such as aggressiveness control and assertive training.

In this sense, social acceptance and non-rejection depend more on what the person can learn about the social behavior (like in the case of social skills as behavioral characteristics than can be trained and learned), but can be facilitated by the desire to be in a social relationship (sociable personality trend). Sociable persons obviously tend to engage more in social situations, as well as to learn socially able conducts. This aspect calls for new and more controlled studies, which go beyond the limit of this study, which had a correlational design. Although the collinearity of the independent variables was controlled for, new studies with larger samples (aiming to identify the model) can be developed using structural equations or path analysis modeling, as the social skills and socialization are latent variables.

Overall, the age and situation/type of organized group are variables that affect the variables that explain the acceptance and rejection and should always be considered and controlled. New studies can focus on the analysis of the possibility of a general factor for acceptance/rejection in the group, as well as on studies with greater control over these variables to suggest more homogeneous and consistent results. It should also be taken into account that the people in the research sample presented slightly lower socialization levels, while the social skills levels in this sample were slightly higher (negative and positive low asymmetry, respectively). Hence, new studies, mainly with greater socialization variability can be developed to test whether the effects identified here continue. In addition, in sociometric studies, a larger quantity of groups (classrooms in this case) is relevant and could be better explored in other studies.

\section{References}

Aviezer, H., Trop, Y., \& Todorov, A. (2012). Body cues, not facial expressions, discriminate between intense positive and negative emotions. Science, 338(6111), 1225-1229. doi: $10.1126 /$ science. 1224313

Bartholomeu, D., Carvalho, L. F., Silva, M. C. R., Miguel, F. K., \& Machado, A. A. (2011). Aceitação e rejeição entre pares e habilidades sociais em universitários [Acceptance and rejection between peers and social skills in college students]. Estudos de Psicologia (Natal), 16(2), 155-162. doi:10.1590/S1413-294X2011000200006
Bartholomeu, D., Montiel, J. M., \& Bernstein, M. J. (2014). Social skills and study group acceptance: Research with higher education. International Journal of Advances in Psychology (IJAP), 3(4), 111-119. doi:10.14355/ ijap.2014.0304.02

Bartholomeu, D., Montiel, J. M., \& Pessotto, F. (2011). Sociometria e habilidades sociais em alunos do ensino médio [Sociometry and social skills in high school students]. Estudos Interdisciplinares em Psicologia, 2(2), 211-228. Retrieved from www.uel.br/revistas/uel/index. php/eip/article/download/10928/9553

Bartholomeu, D., Nunes, C. H. S. S., \& Machado, A. A. (2008). Traços de personalidade e habilidades sociais em universitários [Personality traits and social skills in college students]. Psico-USF, 13(1), 41-50. doi:10.1590/ S1413-82712008000100006

Bernstein, M. J., Sacco, D. F., Young, S. G., Hugenberg, K., \& Cook, E. (2010). Being "in" with the in-crowd: The effects of social exclusion and inclusion are enhanced by the perceived essentialism of ingroups and outgroups. Personality and Social Psychology Bulletin, 36(8), 9991009. doi:10.1177/0146167210376059

Bueno, J. M. H., Oliveira, S. M. S. S., \& Oliveira, J. C. S. (2001). Um estudo correlacional entre habilidades sociais e traços de personalidade [A correlational study of social skills to personality traits]. Psico-USF, 6(1), 31-38. doi:10.1590/S1413-82712001000100005

Currie, T. E., \& Little, A. C. (2009). The relative importance of the face and body in judgments of human physical attractiveness. Evolution and Human Behavior, 30(6), 409-416. doi:10.1016/j.evolhumbehav.2009.06.005

Del Prette, Z. A. P., \& Del Prette, A. (2001). Inventário de habilidades sociais (IHS-Del-Prette): Manual de aplicação, apuração e interpretação [Inventory social skills: Application manual, assessment and interpretation]. São Paulo, SP: Casa do Psicólogo.

Del Prette, Z. A. P., Del Prette, A., \& Barreto, M. C. M. (1998). Análise de um Inventário de Habilidades Sociais (IHS) em uma amostra de universitários [Analysis of a Social Skills Inventory (IHS) applied to a sample of college students]. Psicologia: Teoria e Pesquisa, 14(3), 219-228. Retrieved from https://revistaptp.unb.br/index.php/ptp/article/ view/1507/468

Del Prette, Z. A. P., Del Prette, A., De Oliveira, L. A., Gresham, F. M., \& Vance, M. J. (2012). Role of social performance in predicting learning problems: Prediction of risk using logistic regression analysis. School Psychology International, 33(6), 615-630. doi:10.1177/0020715211430373

DeWall, C. N., Twenge, J. M., Koole, S. L., Baumeister, R. F., Marquez, A., \& Reid, M. W. (2011). Automatic emotion regulation after social exclusion: Tuning to positivity. Emotion, 11(3), 623-636. doi:10.1037/a0023534 
Feitosa, F. B., Del Prette, Z. A. P., \& Del Prette, A. (2012). Social skills and academic achievement: The mediating function of cognitive competence. Temas em Psicologia, 20(1), 61-70. Retrieved from http://pepsic.bvsalud.org/ $\mathrm{pdf} / \mathrm{tp} / \mathrm{v} 20 \mathrm{n} 1 / \mathrm{v} 20 \mathrm{n} 1 \mathrm{a} 06 . \mathrm{pdf}$

Ferreira, B. C., \& Del Prette, Z. A. P. (2013). Programa de expressividade facial de emoções e habilidades sociais de crianças deficientes visuais e videntes [Facial expression of emotions and social skills of visually impaired and sighted children]. Psicologia: Reflexão e Crítica, 26(2), 327-338. doi:10.1590/S010279722013000200013

Freitas, C. L., \& Del Prette, Z. A. P. (2015). Social Skills Rating System Brazilian Version: New exploratory and confirmatory factorial analyses. Avances en Psicología Latinoamericana, 33(1), 135-156. doi:10.12804/ ap133.01.2015.10

Garg, N., Favre, S., Salamin, H., Hakkani-Tür, D., \& Vinciarelli, A. (2008). Role recognition for meeting participants: An approach based on lexical information and social network analysis. Proceedings of the ACM International Conference on Multimedia, 16, 693-696. Retrieved from: http://publications.idiap.ch/downloads/ papers/2008/Favre_ACMMULTIMEDIA_2008.pdf

Gifford-Smith, M. E., \& Brownell, C. A. (2003). Childhood peer relationships: Social acceptance, friendships, and peer networks. Journal of School Psychology, 41(4), 235285. doi:10.1016/S0022-4405(03)00048-7

Gresham, F. M., \& Stuart, D. (1992). Stability of sociometric assessment: Implications for uses as selection and outcome measures in social skills training. Journal of School Psychology, 30(3), 223-231. doi:10.1016/00224405(92)90007-R

Hayden-Thomson, L., Rubin, K. H., \& Hymel, S. (1987). Sex preferences in sociometric choices. Developmental Psychology, 23(4), 558-562. doi:10.1037/00121649.23.4.558

Kraus, M. W., Oveis, C., Allison, M. L., Young, R. C., Tauer, J., \& Keltner, D. (2014). Teasing, taunting, and the politics of politeness: High sociometric status is associated with expectation-consistent behavior. PLoS One, 9(8), e104737. doi:10.1371/journal.pone.0104737

Malinauskas, R., \& Emeljanovas, A. (2013). Specificity of school children's social skills during physical education classes. Croation Journal of Education, 15(4), 51-68. Retrieved from http://hrcak.srce.hr/114963

McKown, C., Gumbiner, L. M., \& Johnson, J. (2011). Diagnostic efficiency of several methods of identifying socially rejected children and effect of participation rate on classification accuracy. Journal of School Psychology, 49(5), 573-95. doi:10.1016/j.jsp.2011.06.002
Montiel, J. M., Pessotto, F., \& Bartholomeu, D. (2014). Habilidades sociais e status sociométrico em crianças do ensino fundamental [Social skills and sociometric status in children of basic education]. Revista Sul Americana de Psicologia, 2(2), 251-272. Retrieved from http://www. revista.unisal.br/am/index.php/psico/article/view/46/65

Morais, M. L. S., Otta, E., \& Scala, C. T. (2001). Status sociométrico e avaliação de características comportamentais: Um estudo de competência social em pré-escolares. Psicologia: Reflexão e Crítica, 14(1), 119131. doi:10.1590/S0102-79722001000100010

Moreno, J. L. (1972). Fundamentos de la sociometria [Who shall survive?] (J. García Bouza \& S. Kars, Trads., 2a ed.). Buenos Aires, Argentina: Paidós.

Nunes, C. H. S. S., \& Hutz, C. S. (2007a). Construção e validação da escala fatorial de socialização no modelo dos Cinco Grandes Fatores de Personalidade [Development and validation of an Agreeableness scale in the Big Five personality model]. Psicologia: Reflexão e Crítica, 20(1), 20-25. doi:10.1590/S0102-79722007000100004

Nunes, C. H. S. S., \& Hutz, C. S. (2007b). Escala Fatorial de Socialização-Manual técnico [Factorial Socialization Scale - Technical Manual]. São Paulo, SP: Casa do Psicólogo.

Selfhout, M. H., Branje, S. J. T., Delsing, M., ter Bogt, T. F. M., \& Meeus, W. H. J. (2009). Different types of Internet use, depression, and social anxiety: The role of perceived friendship quality. Journal of Adolescence, 32(4), 819833. doi:10.1016/j.adolescence.2008.10.011

Serrat-Capdevila, A., Browning-Aiken, A., Lansey, K., Finan, T., \& Valdés, J. B. (2009). Increasing social-ecological resilience by placing science at the decision table: The role of the San Pedro Basin (Arizona) decision-support system model. Ecology and Society, 14(1), 37. Retrieved from http://ecologyandsociety.org/vol14/iss1/art37/ES2008-2839.pdf

Silva, C. E., Oliveira, R. V. B., Bandeira, D. R., \& Souza, D. O. (2012). Violência entre pares: Um estudo de caso numa escola pública de Esteio/RS [Violence among peers: A case study in a public school in Esteio/RS - Brazil]. Psicologia Escolar e Educacional, 16(1), 83-93. doi:10.1590/S141385572012000100009

Sisto, F. F. (2003). Escala de Traços de Personalidade para Crianças - ETPC [Personality Traits Scale for Children ETPC]. São Paulo, SP: Vetor.

Verosky, S. C., \& Todorov, A. (2013). When physical similarity matters: Mechanisms underlying affective learning generalization to the evaluation of novel faces. Journal of Experimental Social Psychology, 49(4), 661669. doi:10.1016/j.jesp.2013.02.004

Vinciarelli, A., Pantic, M., \& Bourlard, H. (2009). Social signal processing: Survey of an emerging domain. Image and Vision Computing, 27(12), 1743-1759. doi:10.1016/j. imavis.2008.11.007 
Vinciarelli, A., Pantic, M., Bourlard, H., \& Pentland, A. (2008). Social signal processing: State-of-the-art and future perspectives of an emerging domain. Proceedings of the ACM International Conference on Multimedia, 16, 1061-1070.

Daniel Bartholomeu is a Professor of the Centro Universitário Salesiano de São Paulo.

José Maria Montiel is a Professor of the Centro Universitário FIEO.

Received: Jun. 22, 2015

1st Revision: Nov. 18, 2015

Approved: Jun. 07, 2016

How to cite this article:

Bartholomeu, D., \& Montiel, J. M. (2017). Behavioral and personality predictors of acceptance and rejection in university. Paidéia (Ribeirão Preto), 27(68), 272-280. doi: 10.1590/1982-43272768201704 